\title{
EPIPHYTIC MICROFLORA OF RICE (ORYZA SATIVA L.) AS A SOURCE OF STRAINS WITH AGRONOMICALLY USEFUL PLANT PROPERTIES
}

\section{Yakubovskay A. I.}

Institute of Agriculture Crimea NAAS, Department of Microbiology 107 Karl Marks str., Simferopol region, Gvardeyskoe 97513, Ukraine E-mail: midyza_kiss@mail.ru

The paper covers the study of morphological, physiological and biochemical properties of associative microorganisms isolated from rice roots and plants' response on inoculation. The agronomically useful properties, such as growth stimulation, ability to fix nitrogen and mobilize phosphates were observed. The positive influence of isolated bacteria on growth and development of rice plants was observed.

Key words: epiphytic microflora, associative microorganisms, rice.

Formation of soil fertility is influenced by a complex of natural and anthropogenic factors, among which the most important is the vital activity of soil microorganisms [1-4]. Microorganisms ensure the biological cycle of substances in nature, are involved in the transformation of mineral and organic compounds, synthesize biologically active substances, affect physical and chemical properties of the soil and regulate plant growth. Composition and number of microbial associations in soils agrocoenoses determines the biological buffering of soils under the adverse influence of various technological factors.

Rice cultivation cause significant problems related to the soil conditions. Thus, in order to obtain high yields of rice the intensive technologies are used, including high yield potential varieties, mineral and organic fertilizers, chemical pesticides against diseases, pests and segetal plants). In some cases the crop is grown for 2-3 years in a row or in monoculture that results in increasing doses of mineral fertilizers [7]. Besides, since the irrigation of rice in Ukraine is performed by means of short flooding (water layer is missing at the beginning and end of the growing season), that creates the optimal conditions for the accumulation of pathogens and therefore increase of pesticides application leading to environmental pollution. Researchers from different countries have established that prolonged flooding of rice fields decreases humus content in soil, followed by waterlogging and salinization, which also reduces soil fertility, affects the hydrolytic treatment of surrounding land and bays $[8,9]$.

One of the possible optimization ways of rice cultivation technology is use of microbial preparations which stimulate development of useful forms of microorganisms that can compete with the indigenous microbiota and dominate in plants rhizosphere $[5,6]$. At this the promising area of research, related to the selection of agronomically active strains is seemed to be the cultivation of isolates of microbial communities of epiphytic microbiota. Epiphytes could be more adapted to different plant species and be more efficient while using them as the basis for biological preparations.

The aim of current research was to isolate active strains of epiphytic bacteria capable to colonize the roots of rice and form effective associations with plants.

Objects and research methods. Given research was performed on roots of rice plants grown on meadow - chestnut soil, selected from checks where rice was cultivated in monoculture for 10 years and microorganisms isolated from the aerial roots.

Isolation of associative microorganisms was performed using advanced method proposed by Sherstoboyev M.K., Melnychuk T.M. and Melnyk L.I. [11]. Roots, free of soil and populated with associative microorganisms, were obtained in sterile vegetation experiment. Roots were removed, washed and, after a series of dilutions, solution was surface plated in Petri dishes on agar medium cabbage medium \# 19 [12]. The plates were incubated at $28{ }^{\circ} \mathrm{C}$. Colony forming units (CFU) were 
count at $3^{\text {rd }}$ and $5^{\text {th }}$ days. Abundance and occurrence frequency of morphotypes was calculated by the method of qualitative determining of rhizosphere microorganisms [13].

Agronomically useful properties of selected bacteria were studied on Vynogradsky medium without nitrogen (nitrogen fixation ability) and Muromtsev medium - to determine the ability of microorganisms to dissolve soluble phosphates. Phytotoxicity of bacteria was studied using the biological assay on wheat seeds [14]. The presence of phytotoxins in the bacterial culture was determined by its influence on plants growth taking into the account the percentage of sprouted seeds and measuring plants seedling length (embryonic shoot and roots).

To study the effect of isolates on rice plants the flooding and drying of the soil was simulated close to the real field conditions. Later, the length of roots and shoots as well as their airdry mass were determined. Experiments planning and statistical analysis of data were performed by the Dospekhov B. A. [15].

Results and discussion. Among the thirteen isolated morphotypes of bacteria from epiphytic mikrobocoenosis on aerial roots of rice, five, which number was at least $10 \%$ of the total bacteria count, appeared to be dominant (Table 1).

Table 1. Abundance of morphotypes of bacteria, isolated from air roots of rice

\begin{tabular}{|c|l|c|c|}
\hline $\begin{array}{c}\text { \#\# of } \\
\text { isolate }\end{array}$ & \multicolumn{1}{|c|}{ Appearance of colonies, medium \#19 } & $\begin{array}{c}\text { Occurrence } \\
\text { frequency, \% }\end{array}$ & $\begin{array}{c}\text { Abundance, } \\
\%\end{array}$ \\
\hline 1 & $\begin{array}{l}\text { Rounded, 2-3 mm in diameter, smooth surface, even } \\
\text { edges, darker in the middle, rough rim of gray-blue } \\
\text { color, shiny, flat }\end{array}$ & 10 & 2.6 \\
\hline 2 & $\begin{array}{l}\text { Rounded, 5-7 mm in diameter, smooth surface, convex, } \\
\text { shiny, even edges, off-white or transparent }\end{array}$ & 100 & 34.4 \\
\hline 3 & $\begin{array}{l}\text { Rounded, 2-4 mm in diameter, smooth surface, even } \\
\text { edges, shiny, flat, orange }\end{array}$ & 80 & 10.6 \\
\hline 4 & $\begin{array}{l}\text { Rounded, 1-1.5 mm in diameter, even edges, smooth } \\
\text { surface, convex, shiny, white }\end{array}$ & 50 & 3.6 \\
\hline 5 & $\begin{array}{l}\text { Rounded, 5 mm in diameter, smooth surface, even } \\
\text { edges, convex with white rims }\end{array}$ & 50 \\
\hline 6 & $\begin{array}{l}\text { Rounded, 1-5 mm in diameter, smooth surface, even } \\
\text { edges, flat, mat, white }\end{array}$ & 50 & 16.6 \\
\hline 7 & $\begin{array}{l}\text { Rhizoidal shape, 7-8 mm in diameter, smooth surface, } \\
\text { flat, shiny, with a clear round midst }\end{array}$ & 10 & 0.8 \\
\hline 8 & $\begin{array}{l}\text { Rounded, 2 mm in diameter, smooth surface, even } \\
\text { edges, shiny, convex, concave from the middle, white }\end{array}$ & 10 & 10.3 \\
\hline 9 & Rhizoidal shape, 3 mm in diameter, mat, flat, cream & 10 & 13.4 \\
\hline 10 & $\begin{array}{l}\text { Irregular shape, 8-10 mm in diameter, flat, mat, rough } \\
\text { surface, orange }\end{array}$ & 30 & 0.6 \\
\hline 11 & $\begin{array}{l}\text { Rounded, 5 mm in diameter, smooth surface, even } \\
\text { edges, convex, shiny, pale pink }\end{array}$ & 10 & 10 \\
\hline 12 & $\begin{array}{l}\text { Rounded, smooth surface, even edges, flat, shiny, } \\
\text { bright-red } \\
\text { edge, 2-3 mm in diameter, even edges }\end{array}$ & 10 \\
\hline
\end{tabular}

Morphotypes of seven representatives out of thirteen $(53.5 \%)$ were capable of nitrogen fixation, whereas intensive growth was observed only in two cultures. $92.3 \%$ of isolates have shown 
growth of various intensity on the Muromtsev cultural media. Among the studied isolates seven were capable of nitrogen fixation and phosphorous mobilization.

As is known, many rhizobia produce physiologically active substances that can stimulate or inhibit plants growth and development. It was shown that isolated bacteria had promoted germination parameters in wheat test-culture by $7.7-30.8 \%$ as compared to control (Table 2).

Table 2. Influence of bacterial isolates on wheat seed germination parameters

\begin{tabular}{|l|c|c|c|}
\hline Variants & $\begin{array}{c}\text { Number of } \\
\text { germinated } \\
\text { seeds, } \\
\text { pcs. }\end{array}$ & $\begin{array}{c}\text { Seeds } \\
\text { germination, \% }\end{array}$ & Increment to control, \% \\
\hline Control & 13.0 & 65 & - \\
\hline \multicolumn{3}{|c|}{ Isolates } \\
\hline ARR 1 & 16.0 & 80 & 23.1 \\
\hline ARR 2 & 16.0 & 80 & 23.1 \\
\hline ARR 3 & 15.0 & 75 & 15.4 \\
\hline ARR 5 & 17.0 & 85 & 30.8 \\
\hline ARR 6 & 15.0 & 75 & 15.4 \\
\hline ARR 7 & 17.0 & 85 & 30.8 \\
\hline ARR 9 & 17.0 & 85 & 30.8 \\
\hline ARR 10 & 15.0 & 75 & 15.4 \\
\hline ARR 11 & 16.0 & 80 & 23.1 \\
\hline ARR 13 & 14.0 & 70 & - \\
\hline & 2.81 & - & 7.7 \\
\hline
\end{tabular}

Eight isolates were capable to stimulate root growth, four of which had also stimulated growth of wheat seedlings. Three isolates had enhanced development of both roots (increase of length by $31.5 \%, 20.8 \%$ and $32.6 \%$ to control) and wheat germs (respectively $6.4 \%, 4.4 \%$ and 6.4\%) (fig. 1).

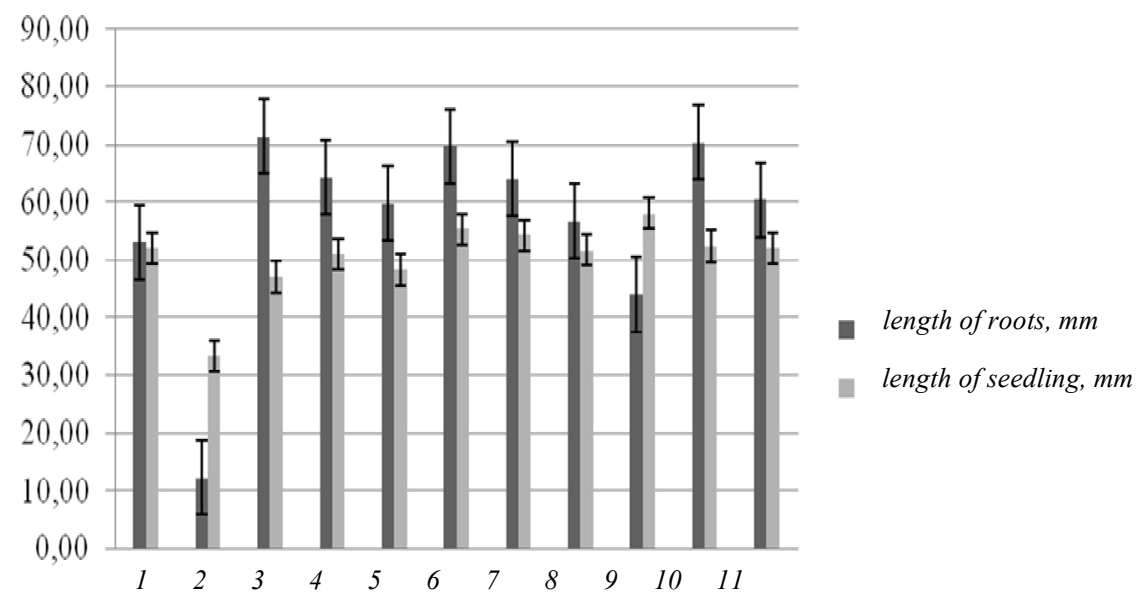

Figure 1. Influence isolates the length of roots and shoots of wheat seeds

1 - control; $2-A R R 1 ; 3-A R R 2 ; 4-A R R 3 ; 5-A R R$ 5; 6-ARR 6; $7-A R R$ 7; 8-ARR 9;10-ARR 10;11-ARR 11;12-ARR 13. 
Isolates effect on the development of rice plants was studied in the green house experiment. The slight increase of seedlings length in the variant with of seeds inoculation with ARR 7 isolate by $1.5 \%$ was observed. In variant with ARR 3 isolate the $30.3 \%$ increase of roots length and 5.4\% increment of their air-dry weight comparing to the control was noticed.

According to the primary results the three isolates: ARR 3, ARR 6, ARR 7 were selected for the subsequent study in the field conditions. ARR 7 isolate was obtained from the colonies of orange color, irregular shape, diameter $8-10 \mathrm{~mm}$, flat, matte, with a rough surface, frequency of occurrence $-13.4 \%$ (Fig. 2). Occurrence frequency of other bacteria morphotypes that formed round colonies, $1-5 \mathrm{~mm}$ in diameter, with smooth surface, level edges, flat, dull and white - was $50 \%$ (selected isolate ARR 3) (Fig. 2). At cultivation on cabbage agar, the high growth rate of these morphotypes was observed.

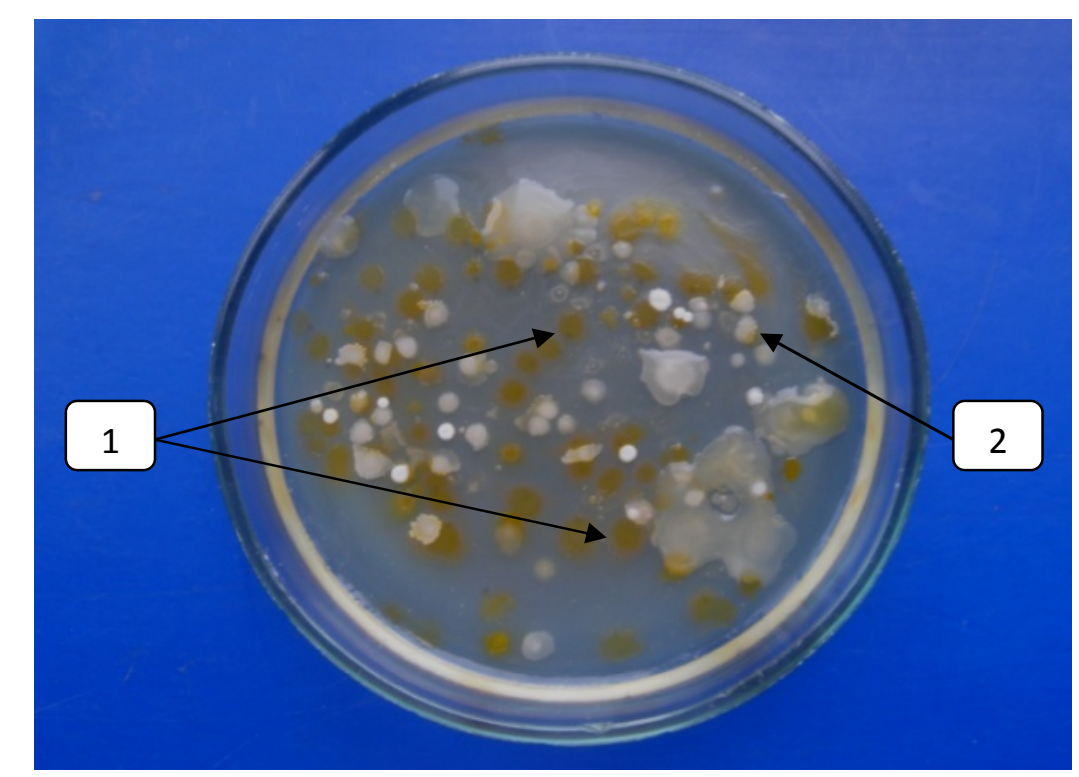

Figure 2. Morphotypes of epiphytic microbiota of rice air-roots (1-ARR 7; $2-A R R 3)$

Thus, the initial study of strains efficiency had revealed that isolates had promoted seeds germination, but in different degrees (from $7.7 \%$ to $30.8 \%$, compared to control). Eight isolates were able to stimulate root growth of wheat seeds, and four - to promote growth of wheat seedlings. Isolates ARR 6, ARR 7, ARR 10 were able to stimulate growth of both roots and shoots.

Among the studied bacteria three isolates with the most distinguished agronomically useful properties (growth stimulation, nitrogen fixation, mobilization of phosphorous) were selected for further research. 